\title{
Design of a gamified tool for the development of citizenship competencies
}

\section{Maira Camila Paba-Medina, Julieth Katherin Acosta-Medina, Martha Liliana Torres- Barreto \\ Escuela de estudios industrials y empresariales, Universidad Industrial de Santander, Colombia.}

\begin{abstract}
The DidacTIC project emerges as a proposal in face of high levels of desertion in virtual education, and the latent need to develop citizen competencies in the Colombian context. It consists in the joint development of a platform that will extract information from the Learning Management Systems and a motivational didactics tool based on gamification principles, designed to reinforce the teaching and learning process in the subject of citizen competencies. This document evidences the methodology applied to the design of the gamified tool. The methodology used was based on the "player-centered design", so, various information collection tools were used to gather and categorize the main characteristics of users (motivations, sociodemographic and behavioral data) and design the game accordingly. From this, the findings show that users have a high impact, such that, the graphical interface and content present a close relationship with real-life situations.
\end{abstract}

Keywords: Gamification; citizenship competencies; machine learning; artificial intelligence; education; ICT. 


\section{Introduction}

Virtual education in Colombia has had a rattling growth in recent years, according to data from "Ministerio de Educación de Colombia" (2018). Also, in recent years, the growth in the number of enrollments in the virtual mode of higher education was $98.9 \%$, manifesting thus the importance to undertake processes of continuous improvement over this teaching modality, to ensure the quality of education.

A big challenge for virtual education is the motivation of both teachers and students. Teachers, who seek to create emotions in their students with the encouragement to raise awareness towards learning, and students, who sometimes are not aware of the purpose or goal of a particular academic activity. Motivation is fundamental in every educational modality, since without it, hardly anyone would undertake a personal or academic level work effort towards competencies development (Romero \& Pérez, 2009). Besides, motivation becomes more relevant in online training courses because distance, solitude and special requirements for student autonomy are factors that influence their permanence/attendance.

Thus, if learning is understood as a continuous process, it can be intuited that it requires permanent motivation, both for undertaking it as to prolong it until it reaches the proposed objectives, and that is precisely one of the greatest efforts in virtual classrooms. Although students may have a notable will at the beginning of every course, usually it is going to decay over time as topics advance and the training course reaches more complexity. In this context, there are excellent alternatives like the design and application of participative or interactive activities, such as recreational activities or formal games. These, framed in a gamified ambiance, contrast in some/a major way with the more passive and regular activities within the virtual classroom. In the face of these requirements from the virtual educational model, the DidacTIC project seeks to take advantage of gaming, artificial intelligence and machine learning to design a didactic tool based on gamification that will be found in the Learning Management Systems (LMS) of virtual training courses. This tool will focus on the development and strengthening of citizenship competencies in students, enabling them a proper posture and interaction within society.

Being so, this project seeks to answer the needs observed in different studies, which have considered the development of citizenship competencies from diverse educational perspectives (Castro Annicchiarico, 2014). Particularly, in the Colombian context, it increases the relevance of these competencies due to the governmental efforts to find alternatives to resolve social issues (social exclusion, corruption perception index, violence, among others) (ICFES, 2018a), and the obtained results in "Pruebas Saber" where it became evident that $49 \%$ of young people accept violence in any of its manifestations and $41 \%$ of young people accept disobeying the law (Schulz et al., 2016). 
So being, it is justified the need for citizenship competencies appropriation in every educational setting when using innovative and attractive resources for the students, such as Information and communications technology (ICT) tools. In this way, the objective of the present study is to design a gamified tool to motivate and develop citizenship competencies in virtual education students; it should be noted that this research is part of the DidacTIC project.

\section{Theoretical framework}

This research is based on the concepts of gamification and citizenship skills, as they gave rise to the DidacTIC project. On one hand, gamification is the use of typical elements of games in non-gaming contexts" (Llorens-Largo et al., 2016) and it is considered as a promising educational approach to the extent that it can motivate, increase commitment, strengthen knowledge and at the same time it entertains (Katsaounidou et al., 2019). Various researches have studied the impact of gamification on the development of citizenship competencies, these are considered as the set of knowledge, cognitive, emotional and communicative skills that, together, make it possible or an individual to act in a constructive and productive way within society (ICFES, 2018b). A good example related to this research is the European Union's project: WeAreEurope, an online game created to educate 6-10 yearold students in citizenship competencies through gamification (Bratitsis et al., 2017).

Within this context, the DidacTIC project uses moral dilemmas, which are brief stories in which a character faces a complex moral situation, and, in that context, each user must decide about their future actions, limited to various alternatives, each one with positive and negative implications. Moral dilemmas allow the development of cognitive skills, referring to fundamental mental abilities to exercise citizenship competencies, since questions and insights related to these situations are supposed to increase civic knowledge. On the other hand, emotional skills are increased to the extent that moral questioning makes it possible to develop empathy for the characters, increasing the recognition of their own emotions and identifying the appropriate attitudes and behavior, finetuning their Emotional Inteligence. Finally, communication skills are improved since discussions that arise from dilemmas help develop the skills required to establish a constructive dialogue.

\section{Methodology}

The methodology used in this project comes from the Player-Centered Design proposed by Kumar \& Herger, (2013), based at the same time in the User-Centered Design (UCD), an iterative process in which designers focus on the users and their needs in every phase of the project. This method suggests a five-step process for the design of an effective gamification 
experience, which represents the phases of this investigation. Each of them is described below along with the tools used in the data collection process.

(1) Recognition of user profiles for the definition of their most important characteristics: age, skills, and abilities; these factors were obtained from surveys, interviews and similar studies found in the literature. (2) Identification of the mission and the learning objectives, determined by a Factor weighting method. (3) Understanding the intrinsic and extrinsic motivations of the user through the construction of empathy maps and journey maps. (4) Definition of the mechanics, in other words, the history, characters, missions, levels, points, badges, leaderboards, and other elements to use within the tool. (5) Administration, monitoring, and mediation of every advance of the tool, to validate and improve it according to the user`s opinions obtained through proof of concept.

\section{Results}

\subsection{User Profiles}

Initially, to recognize the users' main features, a literature review was conducted about the students and teachers from the academic courses in virtual mode. In this review, sociodemographic and behavioral data was identified (Acevedo et al., 2015; Facundo Díaz, 2009; Rodríguez Albor et al., 2014), from which, three preliminary profiles of students and teachers were created.

Afterwards, to verify the designed pre-profiles, polls were created and conducted to 132 students and 52 teachers of virtual education; also, four particular teachers from this modality were interviewed. The information obtained generated four student profiles and three teacher profiles, summarized in Table 1.

\subsection{Learning objectives}

Afterward, a factor weighting method based on the Delphi method was used to determine which of the seven types of citizenship competencies recognized by the Colombian Ministry of National Education, would be the most relevant. As a result, and based on a quartile analysis, it was found that written communication and cognitive skills, associated with knowledge about citizenship education, will be the central theme of the gamified tool.

\subsection{User's intrinsic and extrinsic motivations}

Additionally, to comprehend user motivation, empathy maps and journey maps were created for the "Newly graduated student" profile. In this study it was found that, the largest number of students fit in this profile. The results indicate that the main intrinsic and extrinsic student motivation is the teacher permanent monitoring and the constant teacher-student communication, as well as development and implementation of innovative activities for their learning. 
Table 1. User profiles

\begin{tabular}{ll}
\hline Profile & Features \\
\hline Ghost student & $\begin{array}{l}\text { Their objective within the course is to steal content and charge to do } \\
\text { activities for other students. }\end{array}$ \\
Working student & $\begin{array}{l}\text { Age between } 30 \text { and } 60 \text { years old, with a stable job, they have the ability } \\
\text { to focus easily, they are competitive, and they have difficulties dealing } \\
\text { with frustration. }\end{array}$ \\
Newly graduated & $\begin{array}{l}\text { Age between } 20 \text { and } 30 \text { years old, just graduated from high school, they } \\
\text { have team work skills and communicate easily, they have difficulty } \\
\text { focusing and acquiring/attaining discipline. }\end{array}$ \\
The student with & $\begin{array}{l}\text { Over } 60 \text { years old, with lots of free time, they have the skills to organize } \\
\text { themselves, they are proactive and love challenges. However, they have } \\
\text { difficulties using current technology. }\end{array}$ \\
Empathetic teacher & $\begin{array}{l}\text { Age between } 30 \text { and } 50 \text { years old, face-to-face and online teachers, they } \\
\text { are very aware of their students dinamics and frequently implement } \\
\text { activities to motivate them. }\end{array}$ \\
Age between 30 and 50 years old, face-to-face and online teacher, fulfill \\
their job and tasks, they struggle to do activities that motivate their \\
students.
\end{tabular}

\subsection{Mechanics of the game}

For the definition of the mechanics, the elements proposed by Knautz (2015), were considered. The following is a brief description of each one:

1. Story: the story takes place in 2120 in Didactic-City, a city where chaos, discourtesy and individualism prevail over the common good, affecting the happiness of the citizens. For this reason, the scientific community decides to develop an artificial intelligence called OSMO that helps making decisions on how to optimize the use of public resources. However, this is considered not to be enough for the necessary improvements, so it is decided to sign up for a new Mayor for the city. The mayor will be represented by the student using the tool, who will face complex decision making to save his city. The city has buildings the user will be able to improve, as well as a power plant, food suppliers and water treatment plants, in which the Mayor must keep high indicators to avoid citizens moving out to another city.

2. Characters: the tool will have a Mayor (avatar selected by user) and an assistant, OSMO, who will be represented by the avatar of a robot. 
3. Missions: the missions will be contained in interaction bubbles with multiple choice questions, moral dilemmas and problem situations, which must be solved by the user to get rewards. Moral dilemmas are short stories in which a character faces a complex situation and must decide on his future actions limited to two alternatives with positive and negative implications each. On the other hand, problem situations are related questions from the perspective of three characters, so the player must make decisions taking into account different points of view. The implementation of these strategies contributes to the appropriation of knowledge about citizenship education. Also, the emotional competences increase as the moral questions will allow developing empathy for the characters and the identification of the appropriate attitudes and behavior towards them. Finally, communication skills are improved because at the time the user writes the arguments of his responses to moral dilemmas, the student will be presented with feedback regarding orthographic, grammatical and linguistic aspects; this evaluation will be generated thanks to artificial intelligence that will be anchored to the game

4. Levels: the tool will have eight levels that must be overcome sequentially by the user. Inside each level, the student must solve 20 missions with multiple choice questions, 6 missions with moral dilemmas, and 1 mission with a problem situation; as well as keeping high indicators in water, food, electricity supply and number of citizens. As the player progresses in the levels, the city area will increase also, which will increase the number of buildings, as well as improve their living conditions, resulting in a more modern city.

5. Points: The tool will grant the user points and coins for overcoming missions. With the coins, the student can build and improve buildings and increase the key indicators of the city (see water, electricity, and food).

6. Leaderboards: A public leaderboard of 10 positions will be generated according to the user scores. Besides, each student can know their position privately.

\subsection{Monitoring and measurement of the progress}

Finally, for the validation of the design, a concept test was conducted to evaluate the tool mechanics and dynamics, that is to say, the rules, limitations and actions done by the user, as well as rewards, missions, levels, characters and story. The test was done in a focus group with online students structured in two parts. Students in the first section learned the concept of the tool and simulated some of its phases, generating general appreciations in the group; during the second stage, the students answered individually an acceptability questionnaire according to their perceptions and opinions. Regarding the contents of the tool, the test results indicate that users expect that moral dilemmas and problem situations have complex real-life issues, also that inside the gamified system there must be some fundamental information granted about the citizenship competencies before the execution of the mission; these considerations will be taken into account in the content design. Besides, regarding the tool 
mechanics, some unconformities were found about the avatar appearance of the Mayor, for this reason, modifications were made, and it can be proposed to the user to choose their avatar from a selection of eight options with multiple characteristics, where each of these represent a type of emotional intelligence according to Howard Gardner (Mercadé, 2019).

\section{Conclusions}

In the education sector, the use of new technologies has enabled students to have a greater number of tools allowing the development of their skills and to better acquire knowledge. The incorporation of new technologies in the teaching and learning processes represents an opportunity for improvement both in the functions performed by the teachers and the ones performed by the students, who learn with greater autonomy and efficiency. However, it is also indispensable a constant accompaniment by a teacher or tutor allowing continuity of the student process, because it was found that, in the online education context, the support of the tutor keeps students alert and aware about their progress, increasing their motivation and improving, therefore, their learning process.

Otherwise, it was found in virtual education, that writing skills development and the acquisition of civic knowledge are of great relevance because they are indispensable for the professional training and citizenship formation, that will enable individuals to understand their role within society. Regarding the gamified tool, it is evident in this case that the graphical user interface and the content is valuable for the users. In this sense, the students made an emphasis on the relation between these elements (characters, moral dilemmas, problem situations, among others) with real-life characteristics. Finally, the development of this project allows concluding that the incorporation of emergent tendencies like gamification in virtual learning environments is an opportunity to improve the teaching and learning process while also making it more enjoyable and motivational for students.

\section{Acknowledgments}

We would like to acknowledge the financial support for the development of this project to the "Universidad Industrial de Santander" and "Sistema General de Regalías fondos de CTel" from "Gobernación de Antioquia" administered through "Patrimonio Autónomo Fondo Nacional de Financiamiento para la Ciencia, la Tecnología y la Innovación" Francisco José de Caldas - MINCIENCIAS -.

\section{References}

Acevedo, D., Torres, J. D., \& Tirado, D. F. (2015). Análisis de los Hábitos de Estudio y Motivación para el Aprendizaje a Distancia en Alumnos de Ingeniería de Sistemas de la 
Universidad de Cartagena (Colombia). Formación Universitaria, 8(5), 59-66. https://doi.org/10.4067/S0718-50062015000500007

Bratitsis, T., Meireles, G., \& Neto, C. (2017). WeAreEurope: An Online Game for European Citizenship Education for Primary School. ECGBL 2017 11th European Conference on Game-Based Learning, 38-46.

Castro Annicchiarico, G. (2014). Psicología desde el Caribe. Psicología Desde El Caribe, 31. http://www.redalyc.org/articulo.oa?id=21331836001

Facundo Díaz, Á. H. (2009). Análisis sobre la deserción en la educación superior a distancia y virtual: el caso de la UNAD - COLOMBIA. Revista de Investigaciones UNAD, 8(2), 117. https://doi.org/10.22490/25391887.639

ICFES. (2018a). Las diferencias y el contexto en los módulos específicos. Documento de análisis de resultados Examen SABER PRO 2017. Módulo de Anális Económico.

ICFES. (2018b). Marco de referencia competencias ciudadanas.

Katsaounidou, A., Vrysis, L., Kotsakis, R., Dimoulas, C., \& Veglis, A. (2019). MAthE the Game: A Serious Game for Education and Training in News Verification. Education Sciences, 9(2), 155. https://doi.org/10.3390/educsci9020155

Knautz, K. (2015). Gamification in der Hochschuldidaktik - konzeption, implementierung und evaluation einer spielbasierten lernumgebung.

Kumar, J., \& Herger, M. (2013). Gamification at Work: Designing Engaging Business Software. Interaction Design Foundation.

Llorens-Largo, F., Gallego-Duran, F. J., Villagra-Arnedo, C. J., Compan-Rosique, P., Satorre-Cuerda, R., \& Molina-Carmona, R. (2016). Gamification of the Learning Process: Lessons Learned. Revista Iberoamericana de Tecnologias Del Aprendizaje, 11(4), $227-$ 234. https://doi.org/10.1109/RITA.2016.2619138

Mercadé, A. (2019). Los 8 tipos de Inteligencia según Howard Gardner: la teoría de las inteligencias múltiples.

Ministerio de Educación de Colombia. (2018). Informe de gestión 2018.

Rodríguez Albor, G., Gómez Lorduy, V., \& Ariza Dau, M. (2014). An analysis of academic performance in Colombia.

Romero, M., \& Pérez, M. (2009). Cómo motivar a aprender en la universidad: una estrategia fundamental contra el fracaso académico en los nuevos modelos educativos. Revista Iberoamericana de Educación, 51, 87-105. http://www.rieoei.org/rie51a04.pdf

Schulz, W., Ainley, J., Fraillon, J., Losito, B., \& Agrusti, G. (2016). IEA International Civic and Citizenship Education Study. 